\title{
Serial Studies on the Metabolism of Human Adipose Tissue. I. Lipogenesis and Free Fatty Acid Uptake and Release in Small Aspirated Samples of Subcutaneous Fat *
}

\author{
Jules Hirsch and R. B. Goldrick $\dagger$ \\ (From the Rockefeller Institute, New York, N. Y.)
}

There is abundant evidence indicating that adipose tissue participates actively in both lipid and carbohydrate metabolism (1). Thus, when incubated with appropriate media, this tissue exhibits impressive rates of lipogenesis from glucose and acetate, as well as a continuous uptake and release of free fatty acids (FFA). Nearly all of this in vitro experimental work has been performed with the rat epididymal fat pad, a paired organ uniquely suited for such investigations. It has been tempting to assume that all of these findings are directly applicable to human adipose tissue; however, the demonstration of marked species differences in the metabolism of serum lipids (2) suggests caution in the transposition of data on tissue lipids from one species to another. Since studies of human adipose tissue metabolism have to date required biopsy or removal of tissue during the highly artificial conditions imposed by surgery, it is understandable that few investigations have been carried out with human tissues. Obviously, a simple, nonsurgical method permitting painless, serial sampling of human adipose tissue for metabolic study could be of considerable value.

For several years an essentially painless, aspiration technique has been used in this laboratory for the removal of small quantities of lipid from human subcutaneous adipose depots for studies of fatty acid composition (3). Recently, this technique has been modified so as to allow the removal of tissue shreds of sufficient size to enable study of several parameters of lipid metabolism.

* Submitted for publication January 27, 1964 ; accepted May 15, 1964.

Supported in part by U. S. Public Health Service grants HE-06222-02 and -03 from the National Heart Institute.

$\dagger$ In receipt of an Overseas Traveling Fellowship from the National Heart Foundation of Australia.
The present communication describes this method and the results obtained when FFA uptake and release as well as glucose and acetate lipogenesis are measured in human subjects.

\section{Materials and Methods}

A) Subjects. Clinical data concerning hospitalized patients on whom adipose tissue aspirations were performed are summarized in Table I. All were patients at the Rockefeller Institute Hospital, and many were maintained on liquid formula diets of known composition (4). Further details of the conditions under which indivduals were studied are given in the text. Results were also obtained on laboratory personnel and medical students, who were free of disease or recent marked weight changes.

$B$ ) Isotopes and reagents. D-Glucose- $\mathrm{C}^{14} 1$ (uniformly labeled), sodium acetate-1-C $C^{14}, 1$ and palmitic acid-1-C $C^{14}$ were obtained commercially.

Defatted bovine albumin (Pentex) ${ }^{3}$ was obtained commercially or was prepared from bovine albumin 4 by the method of Goodman (5), dialyzed against distilled water for 24 hours, diluted to a concentration of 5 to $10 \mathrm{~g}$ per $100 \mathrm{ml}$, and the $\mathrm{pH}$ adjusted to 7.4. Albumin-phosphate buffer ( $\mathrm{pH} 7.4$ ) was prepared by mixing equal volumes of $5 \%$ defatted albumin and double strength phosphate buffer (Krebs' original Ringer without calcium chloride).

C) Aspiration of adipose tissue. The method for obtaining tissue shreds employed a siliconized, standard, venipuncture syringe $(50 \mathrm{ml})$ with a no. 15 needle. The syringe was first wetted with warm, gassed, KrebsHenseleit bicarbonate buffer containing $1 \mathrm{mg}$ glucose per $\mathrm{ml}$ at $\mathrm{pH}$ 7.4. The needle was inserted through skin anesthetized with procaine into any convenient subcutaneous site, usually the buttock, the anterior abdominal wall below the level of the umbilicus, or the lateral aspect of the upper third of the arm. To minimize the

1 New England Nuclear Corp., Boston, Mass.

2 California Corp. for Biochemical Research, Los Angeles, Calif. The unlabeled palmitic acid was supplied by the Hormel Foundation, Austin, Minn.

3 Gallard-Slesinger Chemical Manufacturing Corp., Garden City, N. Y.

4 Armour Pharmaceutical Co., Kankakee, Ill. 
possible effect of procaine on the tissue, the anesthetic was given intracutaneously, and the tissues were promptly removed from a much deeper location. After insertion of the needle into the subcutaneous tissue, the syringe was attached to the needle and the syringe plunger vigorously retracted to approximately the $20-\mathrm{ml}$ mark. With the syringe barrel and withdrawn plunger held firmly in one hand and a roll of skin and subcutaneous tissue in the other, a series of short stabbing motions was made into the fat layer. This combined action of needling and suction enabled the removal of numerous shreds of adipose tissue, each several milligrams in weight. The facility with which tissues are removed depends upon the thickness of the subcutaneous layer; more fat and larger pieces are obtained from obese persons. Sufficient quantities for studies of glucose and acetate lipogenesis as well as FFA release and uptake were usually obtained within a minute; occasionally a repeat puncture was required to obtain sufficient tissue. The tissue was immediately emptied from the syringe into gassed, Krebs-Henseleit bicarbonate buffer contained in a thermos flask at $37^{\circ} \mathrm{C}$. As soon as feasible (within not more than 10 minutes), the small shreds were gently lifted from the buffer with a stainless steel spatula and placed in 10-ml Erlenmeyer flasks containing appropriate media for the study of lipogenesis and FFA uptake or release. Two to five pieces were required for glucose lipogenesis, acetate lipogenesis, or FFA uptake, but at least $100 \mathrm{mg}$ ( 50 or more pieces) was required for the accurate measurement of FFA release.

Since this method is essentially painless, we have been able to perform as many as six adipose tissue aspirations in the same individual during a period of 24 hours without untoward effects. The only complication encountered in over 200 aspirations was hematoma formation; however, this is readily prevented by applying firm pressure to the aspiration site for 10 minutes after the procedure. Aspirations have not been performed in the presence of skin infection, bleeding disorders, or procaine sensitivity.

D) Incubation conditions. The tissues were incubated at $37^{\circ} \mathrm{C}$ in $10-\mathrm{ml}$, tightly stoppered, siliconized Erlenmeyer flasks in a water bath shaker ${ }^{5}$ set at 60 cycles per minute. More rapid shaking led to excessive tissue fragmentation. When bicarbonate buffer was used, each flask was gassed with $95 \% \quad \mathrm{O}_{2}: 5 \% \quad \mathrm{CO}_{2}$ before incubation. For the determination of glucose and acetate lipogenesis, the tissues were incubated for 4 hours in 3 $\mathrm{ml}$ of Krebs-Henseleit bicarbonate buffer ( $\mathrm{pH} 7.4$ ) containing $1 \mathrm{mg}$ of glucose per $\mathrm{ml}$. Glucose- $\mathrm{C}^{14}$, uniformly labeled, or sodium acetate-1-C $\mathrm{C}^{14}$ to provide $0.5 \mu \mathrm{c}$ of radioactivity per $\mathrm{ml}$ was also added.

Fatty acid uptake into adipose lipid was measured after 2-hour incubations. The gas phase was air, and the medium, $3 \mathrm{ml}$ of albumin-phosphate buffer, $\mathrm{pH} \mathrm{7.4,}$ containing $1 \mathrm{mg}$ of glucose and $0.1 \mu \mathrm{c}$ of palmitic acid-1$\mathrm{C}^{14}$ per $\mathrm{ml}$ with unlabeled palmitic acid added to make a total of approximately $0.5 \mu \mathrm{Eq}$ FFA per $\mathrm{ml}$. This

\footnotetext{
5 Eberbach Corp., Ann Arbor, Mich.
}

albumin-palmitic acid complex was prepared by prolonged shaking of a warm solution of defatted albumin with labeled and unlabeled FFA present as a thin, dry film of soap in a round-bottom flask.

E) Extraction and determination of lipid. After incubation, the shreds of tissue were immediately placed in a $1,000-\mathrm{ml}$ beaker filled with cold tap water and gently stirred to wash away isotope as well as fat droplets that accompany the aspirate. This was repeated twice. The washed tissues were then extracted in glassstoppered tubes with heptane: isopropanol: $\mathrm{H}_{2} \mathrm{SO}_{4}$ ( $\mathrm{M}$ solution) as recommended by Dole for FFA extraction (6). The tissues were extracted for at least 1 hour with occasional vigorous shaking. Heptane and water were then added, and samples were removed from the upper (heptane) phase for carboxyl ester determination (7) and for measurement of radioactivity. In some instances, lipid content was gravimetrically determined after solvent evaporation (8). In extracts of both rat and human adipose tissue, we found that the microequivalents of glyceride determined as carboxyl ester and calculated as triolein averaged $98.7 \%$ of the solute weight calculated as microequivalents of triolein. Thus, these determinations could be used interchangeably. The adequacy of the washing procedure was tested by the incubation of briefly boiled tissues in isotope-rich media. Under such circumstances only background counts were found in the heptane upper phase. $\mathrm{C}^{14}$ was counted with an efficiency of 60 to $62 \%$ in a Packard Tri-Carb model 314 AX liquid scintillation counter; as much as $2 \mathrm{ml}$ of heptane upper phase could be added directly to the phosphor [0.4\% 2,5-diphenyloxazole and $0.005 \%$ 1,4-bis-2-(5phenyloxazolyl)benzene in toluene] without quenching.

The above procedure was somewhat modified to determine the net rate of FFA release from tissue fragments. Larger amounts of tissue were incubated in 3 $\mathrm{ml}$ of albumin-phosphate buffer containing $1 \mathrm{mg}$ glucose per $\mathrm{ml}$. At the end of the incubation (usually 2 hours), tissues were separated from the medium by filtration through a small plug of glass wool. Tissue lipids were extracted from the glass wool and attached tissue fragments extracted with $M$ solution. After the addition of water and heptane, samples of the upper phase were taken for carboxyl ester determinations. FFA determinations were carried out on $2 \mathrm{ml}$ of the filtrate by the method of Dole (6). Titratable acidity in an extract of the medium before incubation was subtracted from the value determined after incubation to give a figure for net release of FFA. In most instances the quantities titrated were only 0.05 to $0.25 \mu \mathrm{Eq} F F$; hence titration with $0.01 \mathrm{~N}$ base was found useful. FFA uptake and release were always separately measured in different incubation flasks.

$F)$ Calculations. Data are presented per microequivalent of glyceride (as triolein) or per milligram of lipid. As will be shown, there is little to be gained by presenting the data with reference to nitrogen or DNA content, since the lipid: nitrogen or nitrogen:DNA ratios were remarkably similar from one patient to an- 
other. To correct for variations in the specific radioactivity (SA) of substrates in the medium, the incorporation of isotope into tissue lipid was calculated as micrograms of glucose (or acetate) or microequivalents of FFA incorporated per unit time. Such calculation was done as follows: micrograms of glucose incorporated $=$ (counts per minute per microequivalent in lipid extract/ $\mathrm{SA}$ of glucose in the medium in disintegrations per minute per microgram of glucose $) \times(100 /$ percentage of counting efficiency). For convenience, the glucose and acetate data are given as (microgram/microequivalents) $\times 10^{-4}$ and FFA uptake and release as microequivalents of FFA per milliequivalent of adipose glyceride. One $\mu \mathrm{g} \times 10^{-4}$ is equivalent to $0.56 \mu \mu$ moles of glucose or 1.22 $\mu \mu$ moles of sodium acetate.

It should be clear that such calculations make the assumption that the sole precursor pool is the medium. Since the SA used for these calculations is undoubtedly decreased by dilution within tissue precursor pools, all calculations must be considered only in a relative manner, or as minimal values when considering absolute rates of lipogenesis and esterification.

G) Separation of lipids for determination of isotope distribution. The distribution of isotope in adipose lipid after incubations under a variety of conditions was determined by standard methods of thin-layer silicic acid chromatography (9). Lipid was applied to chromatoplates in milligram quantities, and the lipid classes were separated and quantitatively recovered by already described methods (10). In some instances, a more precise evaluation of the amount of label present within the tissue as FFA was undertaken by ion exchange chromatography. The method of Carlson and Wadström (11) employing Amberlite IRA-400 was used with only minor modifications. During incubations with labeled acetate in albumin-containing media, we found that a sizable fraction of the counts in long chain fatty acids was present in the medium rather than exclusively in tissue. The separation of labeled FFA and acetate in the medium was achieved by extracting the FFA in the medium by the method of Dole (6) and then treating a sample of the heptane upper phase as follows. To $1 \mathrm{ml}$ of upper phase were added $20 \mathrm{ml}$ of heptane and $1 \mathrm{ml}$ of glacial acetic acid. This mixture was then distilled under vacuum from a water suction pump starting at room temperature and gradually increasing to $80^{\circ} \mathrm{C}$. To the residue, $10 \mathrm{ml}$ of heptane was added twice, each time followed by distillation as described above. In this way the heptane-acetic acid azeotrope was completely removed. The residue contained more than $97 \%$ of $\mathrm{C}^{14}$ palmitate counts and less than $0.02 \%$ of $\mathrm{C}^{14}$-acetate counts when these two labeled materials were used in appropriate test systems.

Glyceride fatty acids were methylated by interesterification with methanol (12) and separated by gas-liquid chromatography (13) for an evaluation of isotope distribution among various fatty acids. Four-foot columns (4,400 theoretical plates) of Celite particles coated with Apiezon M (15\% film) were used at a temperature of $197^{\circ}$ C. Methyl esters were trapped in the effluent gas by the method described by Meinertz and Dole (14) for determination of radioactivity.

The same technique of methylation was also found useful for an examination of the distribution of isotope between the glycerol and fatty acid moieties of adipose glycerides. After methylation, the methyl esters were separated from glycerol and other water-soluble components by distribution into two phases (heptane: methanol: water, equal parts by volume). The loss of radioactivity into the lower phase was considered to be equivalent to glycerol labeling.

$H) D N A$ content of adipose tissue. We examined ${ }^{6}$ by microspectrophotometry the Feulgen-stained adipose tissue nuclei of post-mortem specimens from human subjects of widely different body weights. With the two wave length method of microspectrophotometry $(15,16)$, the nuclei were found to be diploid. Furthermore, a careful examination of the sections failed to reveal any multinucleated cells. On the basis of these facts, the DNA content of the adipose tissue was used as an index of cellularity. No correction was made for the nuclei of stromal or other nonadipose cells within the tissue. DNA and carboxyl ester measurements were made on some tissue samples, and nitrogen and carboxyl ester measurements on other samples from the same site, in order to calculate the average fat and nitrogen content per cell. For these calculations the amount of DNA present per cell was assumed to be $7 \times 10^{-6} \mu \mathrm{g}$ (17).

DNA was measured in 10 - to $40-\mathrm{mg}$ samples of tissue carefully selected to avoid contamination with blood that interfered with the final colorimetric determination. The method used was the diphenylamine color reaction with the modifications described by Burton (18).

I) Nitrogen content of adipose tissue. Adipose tissue nitrogen was measured by the colorimetric determination of ammonia as indophenol in samples of tissue subjected to acid digestion. Defatted tissue fragments were digested in a mixture of sulfuric acid, selenium oxychloride, and potassium sulfate as described by Minari and Zilversmit (19). After neutralization, ammonia was determined by the method of Lubochinsky and Zalta (20) with slight modifications. This technique was sufficiently sensitive to determine the nitrogen content of single tissue fragments (about $5 \mu \mathrm{g}$ of nitrogen).

An analysis for protein content (21) was also done on 11 tissue samples. The protein to nitrogen ratio averaged 5.55 , only $11 \%$ lower than 6.25 , thus indicating that the nitrogen determination was primarily measuring tissue protein rather than other nitrogenous constituents.

\section{Results}

A) Size and appearance of tissue fragments. With the exception of occasional aspirations in exceedingly thin individuals, sufficient tissue was

6 Through the kindness of Dr. Arline D. Deitch, Department of Microbiology, Columbia University. 
always obtained on a single puncture for measurement of glucose and acetate lipogenesis as well as FFA uptake and release. In 20 successive aspirations done on 11 adults of average body weight, from 131 to $408 \mu \mathrm{Eq}$ of glyceride was obtained per aspiration ( $1 \mu \mathrm{Eq}$ of glyceride equals approximately $1 \mathrm{mg}$ of tissue by wet weight). The average was 257 with a standard deviation of $85 \mu \mathrm{Eq}$. With obese patients, yields up to 500 $\mu \mathrm{Eq}$ have been obtained. The individual fragments vary from 1 to $10 \mu \mathrm{Eq}$ of glyceride in lipid content, with larger pieces more regularly obtained from obese individuals. When these are examined under the dissecting microscope, they are seen to be intact strands of tissue about $2 \mathrm{~mm}$ in width and varying from 2 to $10 \mathrm{~mm}$ in length. With higher magnification, the myriads of individual cells, each clearly seen, are grouped like densely packed, small bubbles of nearly uniform size. Assuming that the cells are spherical and average $100 \mu$ in diameter, the strips should contain between $10^{4}$ and $10^{5}$ cells.

B) Viability of tissue. By a variety of experiments we have been able to demonstrate the viability of human adipose tissue enzyme systems during in vitro incubation of the strips obtained by needle aspiration. For example, the tissue can be shown to convert radioactive glucose or acetate present in the medium to tissue glycerides. The appearance of glucose label in tissue lipids during an 8-hour incubation at $37^{\circ} \mathrm{C}$ is shown in Figure 1. It is apparent that lipogenesis continues in a nearly linear fashion for close to 4 hours and then gradually diminishes.

Concomitant with glucose and acetate lipogenesis, there is a continuous release and uptake of FFA to and from the medium. FFA uptake as studied by the incubation of tissue in medium containing $\mathrm{C}^{\mathbf{1 4}}$-palmitate-albumin complex is shown in Figure 2. Uptake was approximately linear for the 4-hour period during which it was studied. If, however, the tissues were first placed in boiling water for 30 seconds, there was complete inactivation of uptake, as shown by the lower line. Such linear uptake of FFA is in contrast with the usual exponential uptake found when rat epididymal fat pads are incubated with labeled FFA (22). This difference is most likely due to the absence of appreciable dilution of labeled acids in the medium by newly released FFA when small pieces of human tissue are incubated in a relatively large volume of buffer.

It has not been possible to make systematic observations of the release rate of FFA during different time intervals, since the amount of FFA released per unit of tissue is generally so small

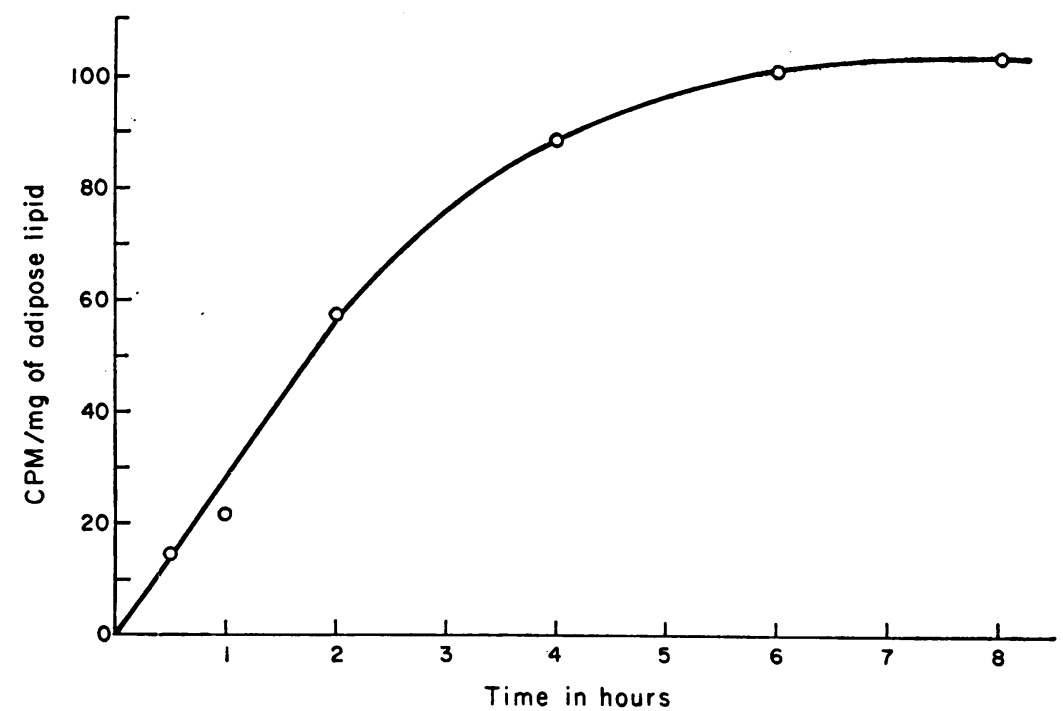

Fig. 1. Rate of glucose lipogenesis. An examination of the rate of incorporation of $\mathrm{C}^{14}$-glucose (uniformly labeled) into the adipose glycerides of subject R.C. The incubation was carried out in bicarbonate buffer containing $1 \mathrm{mg}$ of glucose and $2.5 \mu \mathrm{c}$ of $\mathrm{C}^{14}$-glucose per $\mathrm{ml}$. The tissues removed at zero time were incubated in six separate flasks for the time intervals shown. 


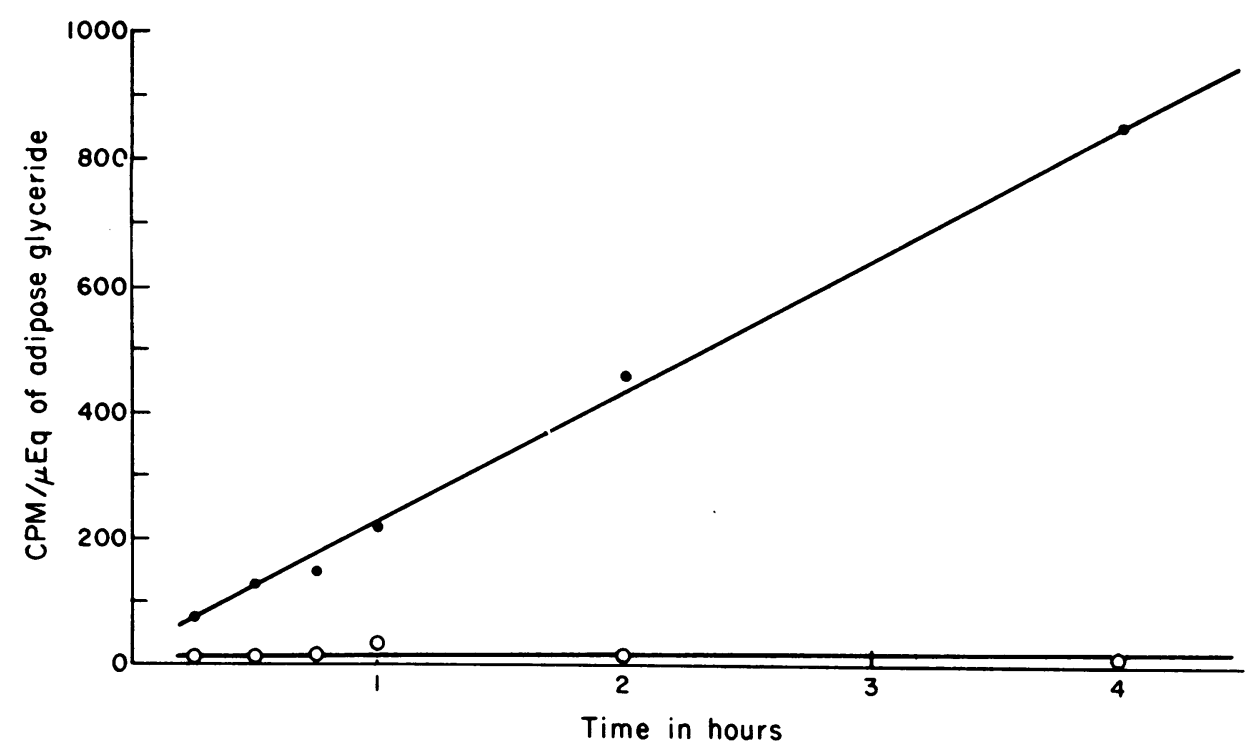

Fig. 2. Rate of fatty acid incorporation into glycerides. Tissue removed from subject J.A.R. was incubated in phosphate buffer containing $25 \mathrm{mg}$ defatted bovine albumin, $1 \mathrm{mg}$ glucose, $0.5 \mu \mathrm{Eq}$ palmitic acid, and $0.125 \mu \mathrm{c}$ of $\mathrm{C}^{14}$-palmitic acid per $\mathrm{ml}$. Points indicated by open circles obtained with tissues boiled for 30 seconds before incubation.

as to require the use of nearly an entire aspirate for duplicate titration of the acid released to the medium. However, occasional observations with unusually large aspirates have revealed a nonlinear release. For example, in one patient (A.M.) the release rate during the first hour of incubation was $-0.58 \mu \mathrm{Eq}$ FFA per $\mathrm{mEq}$ of adipose lipid (thus, a net uptake of acid from the medium), but between 1 and 3 hours of incubation there was a net release of $+1.50 \mu \mathrm{Eq}$ per $\mathrm{mEq}$.

C) Optimal conditions for incubation. Unless otherwise specified, the conditions used in incubations were those given above. In general, hu-

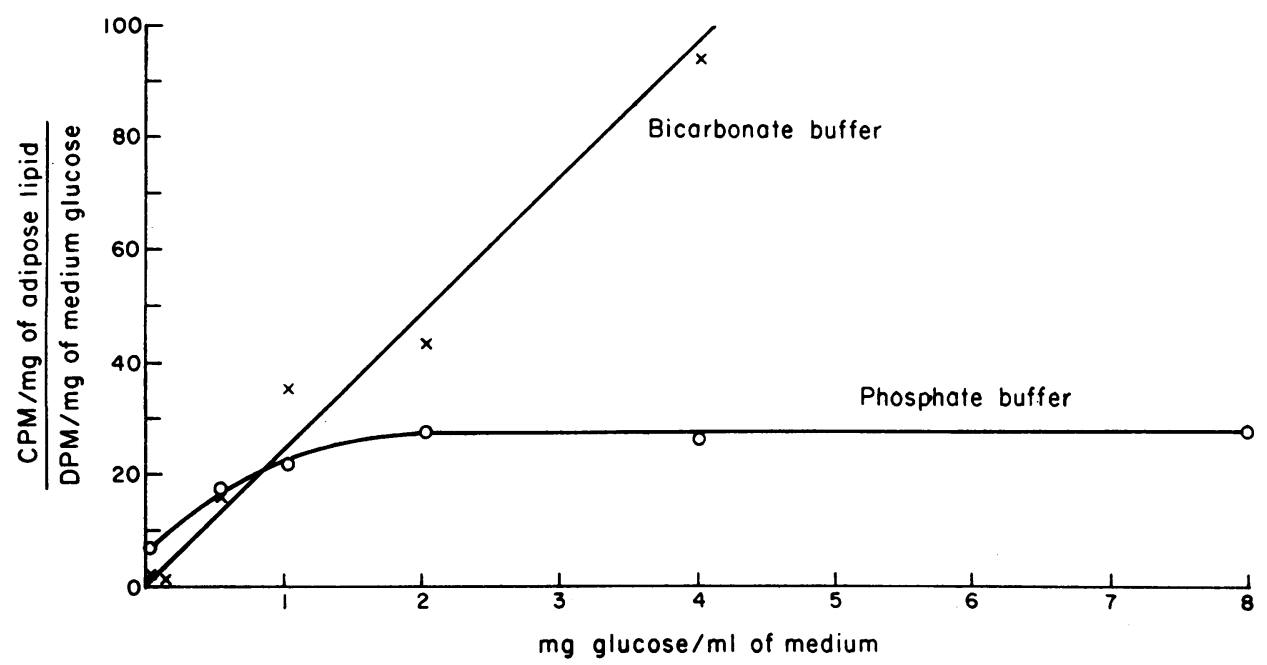

Fig. 3. Buffer EFFECT on RATES of GLUCOSE Lipogenesis. Samples of human adipose tissue from subject R.C. were incubated for 6 hours with $2.5 \mu \mathrm{c} \mathrm{C}^{14}$-glucose and glucose concentrations as indicated in either bicarbonate or phosphate buffers. Ordinate values were calculated to provide a measure of glucose incorporation into adipose glyceride as corrected for differences in glucose specific radioactivity in the medium. 
man adipose tissue fragments have been found to be exceedingly sensitive to minor changes in incubation conditions. A comparison of various incubation conditions was undertaken as described below.

1) Buffer. Since bicarbonate has been shown to be an important precursor in fatty acid synthesis (23), it might be expected that bicarbonate buffer would provide a more favorable environment for glucose and acetate lipogenesis than phosphate buffer. With $1 \mathrm{mg}$ glucose per $\mathrm{ml}$ in the medium, consistent differences in rates of glucose lipogenesis with these two buffers are difficult to demonstrate. If, however, one increases the rate of glucose lipogenesis by increasing glucose concentrations in the medium, the disparity between these two buffers becomes increasingly evident. Thus, in Figure 3 a continuous increase in glucose lipogenesis as a function of glucose concentration in the medium is shown only in bicarbonate buffer. With phosphate buffer a plateau is reached at approximately $2 \mathrm{mg}$ glucose per $\mathrm{ml}$.

The rate of incorporation of acetate label into glyceride is also greatly affected by the buffer composition. This is shown in Table II, in which results from three aspirations of two subjects are

TABLE I

Clinical data

\begin{tabular}{|c|c|c|c|c|c|}
\hline Subject & Age & Sex & Height & Weight & Diagnosis \\
\hline E.H. & 53 & M & $\begin{array}{l}c m \\
178\end{array}$ & $\begin{array}{l}k g \\
67.0\end{array}$ & $\begin{array}{l}\text { Arteriosclerotic heart } \\
\text { disease }\end{array}$ \\
\hline A.G. & 52 & $\mathbf{M}$ & 166 & 62.0 & $\begin{array}{l}\text { Arteriosclerotic heart } \\
\text { disease }\end{array}$ \\
\hline J.A.R. & 45 & $\mathbf{M}$ & 160 & 71.6 & $\begin{array}{l}\text { Arteriosclerotic heart } \\
\text { disease }\end{array}$ \\
\hline J.S. & 62 & $\mathbf{M}$ & 174 & 74.8 & $\begin{array}{l}\text { Arteriosclerotic heart } \\
\text { disease }\end{array}$ \\
\hline S.J. & 27 & $\mathrm{~F}$ & 156 & 100.7 & Obesity \\
\hline S.K. & 22 & $\mathrm{~F}$ & 164 & 117.8 & Obesity \\
\hline A.S. & 38 & $\mathbf{M}$ & 168 & 171.6 & Obesity \\
\hline E.K. & 46 & $\mathbf{M}$ & 160 & 123.0 & Obesity \\
\hline A.G.M. & 21 & F & 154 & 102.1 & Obesity \\
\hline C.K. & 60 & $F$ & 149 & 32.0 & Malnutrition \\
\hline R.C. & 36 & $F$ & 158 & 60.5 & Hypercholesterolemia \\
\hline J.G. & 37 & $\mathbf{M}$ & 180 & 93.0 & Hypercholesterolemia \\
\hline T.H.M. & 40 & $\mathbf{M}$ & 179 & 65.9 & $\begin{array}{l}\text { Carbohydrate-induced } \\
\text { hypertriglyceridemia }\end{array}$ \\
\hline J.H. & 36 & $\mathbf{M}$ & 177 & 80.0 & Normal \\
\hline
\end{tabular}

TABLE II

The effect of buffer on acetate lipogenesis

\begin{tabular}{ccc}
\hline & Bicarbonate & Phosphate \\
\hline & $\mu g / \mu E q \times 10^{-4}$ & $\mu g / \mu E q \times 10^{-4}$ \\
Subject J.H. & $246.8 \pm 1.7^{*}$ & $24.8 \pm 5.7$ \\
Aspiration I $\dagger$ & $\mathrm{n}=4$ & $\mathrm{n}=6$ \\
Subject J.H. & $57.3 \pm 14.9$ & $19.8 \pm 3.8$ \\
Aspiration II & $\mathrm{n}=4$ & $\mathrm{n}=4$ \\
Subject J.S. & $50.2 \pm 9.8$ & $19.9 \pm 5.0$ \\
& $\mathrm{n}=6$ & $\mathrm{n}=6$
\end{tabular}

* All values are given as means \pm standard error of replicate determinations made from different tissue fragments of the same aspirate. Incubations were carried out for 4 hours in $3 \mathrm{ml}$ of buffer with $0.5 \mu \mathrm{c}$ of $\mathrm{C}^{14}$-acetate and 1 $\mathrm{mg}$ glucose per $\mathrm{ml}$. The gas phases were $95 \% \mathrm{O}_{2}: 5 \% \mathrm{CO}_{2}$ for bicarbonate, and air for phosphate buffer.

† Aspirations I and II on subject J.H. were done on different days.

compared in bicarbonate and phosphate buffers. The rates of acetate lipogenesis in phosphate buffer are only 10 to $40 \%$ that found under comparable conditions in bicarbonate buffer.

2) The effect of albumin. One of the more obvious differences between the conditions described above and conditions in vivo is the absence of albumin in the incubation medium. That this may be of importance is suggested by the wellestablished role of albumin in the transport of FFA to and from adipose tissue (24). As shown in Table III, the addition of $5 \%$ defatted bovine albumin (approximately $0.05 \mu \mathrm{Eq}$ FFA per $\mathrm{ml}$ ) has only a slight effect on glucose lipogenesis but produces marked enhancement of acetate lipogenesis. When fat is restored to the albumin by the incremental addition of palmitic acid, the effect of albumin on acetate lipogenesis is greatly reduced in two of the three studies shown. In the third, there appeared to be optimal lipogenesis with albumin containing $0.10 \mu \mathrm{Eq}$ per $\mathrm{ml}$ of FFA and progressive reduction with albumin containing increasing amounts of FFA.

For further exploration of this effect of albumin, FFA in the medium was counted at the end of the incubation. FFA in the medium could be shown to contain from 10 to $20 \%$ the counts found in total tissue glycerides. Since there is much less FFA in the medium than tissue esterified fatty acid, the FFA in the medium had a specific radioactivity ranging from 50 times as high as tissue esterified fatty acids (in the case of defatted albumin) to roughly 10 times as high 
TABLE III

The effect of albumin and FFA in the medium on acetate and glucose lipogenesis

\begin{tabular}{|c|c|c|c|c|c|c|c|c|}
\hline & \multirow[b]{2}{*}{ No albumin } & \multicolumn{7}{|c|}{ Albumin* } \\
\hline & & $\begin{array}{c}0.05 \\
\mu \mathrm{Eq} \\
\mathrm{FFA} / \mathrm{ml}\end{array}$ & $\begin{array}{c}0.10 \\
\mu \mathrm{Eq} \\
\mathrm{FFA} / \mathrm{ml}\end{array}$ & $\begin{array}{c}0.15 \\
\mu \mathrm{Eq} \\
\mathrm{FFA} / \mathrm{ml}\end{array}$ & $\begin{array}{c}0.25 \\
\mu \mathrm{Eq} \\
\mathrm{FFA} / \mathrm{ml}\end{array}$ & $\begin{array}{c}0.50 \\
\mu \mathrm{Eq} \\
\mathrm{FFA} / \mathrm{ml}\end{array}$ & $\begin{array}{c}1.0 \\
\mu \mathrm{Eq} \\
\mathrm{FFA} / \mathrm{ml}\end{array}$ & $\begin{array}{c}5.0 \\
\mu \mathrm{Eq} \\
\mathrm{FFA} / \mathrm{ml}\end{array}$ \\
\hline & $\begin{array}{l}\mu g / \mu E q \\
\times 10^{-4}\end{array}$ & $\underset{\times 10^{-4}}{\mu g / \mu E q}$ & $\begin{array}{l}\mu g / \mu F q \\
\times 10^{-4}\end{array}$ & $\stackrel{\mu g / \mu E q}{\times 10^{-4}}$ & $\stackrel{\mu g / \mu E q}{\times 10^{-4}}$ & $\stackrel{\mu g / \mu E q}{\times 10^{-4}}$ & $\stackrel{\mu g / \mu E q}{\times 10^{-4}}$ & $\begin{array}{l}\mu g / \mu E q \\
\times 10^{-4}\end{array}$ \\
\hline \multicolumn{9}{|l|}{ Acetate } \\
\hline $\begin{array}{l}\text { Subject J.H. } \dagger \\
\text { Aspiration I }\end{array}$ & $\begin{array}{c}57.3 \pm 14.9 \ddagger \\
n=4\end{array}$ & $\begin{aligned} 388.8 & \pm 150.8 \\
\mathrm{n} & =4\end{aligned}$ & & & & $\begin{array}{c}57.5 \pm 8.8 \\
\mathrm{n}=4\end{array}$ & $\begin{aligned} 64.9 & \pm 24.8 \\
\mathrm{n} & =4\end{aligned}$ & $\begin{array}{c}26.7 \pm 9.7 \\
n=4\end{array}$ \\
\hline $\begin{array}{l}\text { Subject J.H. } \\
\text { Aspiration II }\end{array}$ & $\begin{aligned} 52.7 & \pm 11.3 \\
\mathrm{n} & =6\end{aligned}$ & $\begin{aligned} 458.1 & \pm 62.4 \\
\mathrm{n} & =6\end{aligned}$ & $\begin{aligned} 53.9 & \pm 12.2 \\
\mathrm{n} & =6\end{aligned}$ & $\begin{array}{c}30.9 \pm 7.5 \\
\mathrm{n} \equiv 7\end{array}$ & $\begin{array}{c}83.3 \pm 6.1 \\
n=7\end{array}$ & $\begin{array}{c}117.0 \pm 27.2 \\
n=8\end{array}$ & & \\
\hline Subject J.G.† & $\begin{array}{c}5.3 \pm 0.9 \\
n=6\end{array}$ & $\begin{aligned} 24.0 & \pm 2.9 \\
n & =6\end{aligned}$ & $\begin{aligned} 43.1 & \pm 7.2 \\
n & =6\end{aligned}$ & $\begin{array}{c}37.6 \pm 4.6 \\
\mathrm{n}=6\end{array}$ & $\begin{array}{c}32.2 \pm 7.2 \\
\mathrm{n}=6\end{array}$ & $\begin{array}{c}18.3 \pm 2.7 \\
n=6\end{array}$ & & \\
\hline \multicolumn{9}{|l|}{ Glucose } \\
\hline Subject J.G. & $\begin{array}{c}393.0+29.1 \\
n=6\end{array}$ & $\begin{aligned} 426.6 & \neq 29.3 \\
n & =6\end{aligned}$ & & & & & & \\
\hline
\end{tabular}

* Defatted albumin, which contains approximately $0.05 \mu \mathrm{Eq}$ of FFA per ml, was used for the incubations shown in the second column. In incubations shown in the third through eighth columns, fat was restored to defatted albumin with palmitic acid to yield the FFA concentrations shown.

† Aspirations I and II on subject J.H. were performed on different days. The tissues obtained from subject J.G. were obtained at a single aspiration and divided into portions in order to obtain the data shown above.

$\ddagger$ All data are expressed as means \pm standard error. Incubations were carried out for 4 hours in bicarbonate buffer containing 1 mg glucose and, when present, $50 \mathrm{mg}$ bovine albumin per ml. Palmitic acid was added to defatted bovine albumin to provide concentrations of FFA as shown.

(albumin containing $0.50 \mu \mathrm{Eq}$ FFA per $\mathrm{ml}$ ). When no albumin was present, only insignificant FFA counts were present in the medium at the end of incubation; thus, the presence of albumin enabled the release of FFA of high specific activity. Undoubtedly, the newly released FFA is available for reincorporation into the tissue and subsequent esterification. The addition of increasing amounts of unlabeled FFA to the medium might decrease this reincorporation of label into the tissue by simple dilution of specific radioactivity of FFA in the medium. However, the results shown in Table III cannot be explained by this mechanism alone, and elucidation of all details of the mechanism for the observed en- hancement of acetate lipogenesis by defatted bovine albumin will require further study.

3) The effect of insulin. When the rat epididymal fat pad is incubated in the presence of insulin, an increase in lipogenesis is regularly demonstrable (25). However, when human tissues obtained by aspiration are incubated with insulin, increases in lipogenesis are inconstantly found. Table IV shows this lack of effect in human tissue obtained from a nondiabetic woman of normal body weight. This is compared with the clear-cut effect of insulin on the tissues of a large rat, so selected as to be possibly more comparable with adult human tissue than the commonly employed 150 - to $200-\mathrm{g}$ animal. The ad-

TABLE IV

The effect of insulin on glucose lipogenesis

\begin{tabular}{|c|c|c|c|c|}
\hline & Bicarbonate & $\begin{array}{l}\text { Bicarbonate } \\
\text { + albumin }\end{array}$ & $\begin{array}{l}\text { Bicarbonate } \\
+ \text { insulin }\end{array}$ & $\begin{array}{c}\text { Bicarbonate } \\
+ \text { albumin + insulin }\end{array}$ \\
\hline & $c p m / m g$ & $c p m / m g$ & $c p m / m g$ & $\mathrm{cpm} / \mathrm{mg}$ \\
\hline Subject R.C. & $\begin{array}{l}118.6^{*} \\
117.8 \\
141.8\end{array}$ & $\begin{array}{l}233.8 \\
230.0 \\
241.0\end{array}$ & $\begin{array}{l}133.3 \\
121.5 \\
140.6\end{array}$ & $\begin{array}{l}210.8 \\
236.6 \\
212.5\end{array}$ \\
\hline Epididymal pad of $415-\mathrm{g}$ rat & $\begin{array}{l}648.8 \\
579.3 \\
702.9\end{array}$ & $\begin{array}{l}850.2 \\
811.2 \\
967.9\end{array}$ & $\begin{array}{l}1,338.4 \\
1,322.1 \\
1,659.6\end{array}$ & $\begin{array}{l}1,635.4 \\
1,631.9 \\
1,587.0\end{array}$ \\
\hline
\end{tabular}

* Triplicate determinations were done from separate groups of tissue fragments obtained at the same aspiration (subject R.C.) or from strips of epididymal fat pad obtained with the animal under light ether anesthesia. Incubation media contained $1 \mathrm{mg}$ glucose and $2.5 \mu \mathrm{c}$ of $\mathrm{C}^{14}$-glucose per $\mathrm{ml}$. Insulin + bovine albumin were $0.1 \mu \mathrm{U}$ and $35 \mathrm{mg}$ per $\mathrm{ml}$, respectively. 
TABLE V

The effect of insulin on glucose and acetate lipogenesis under different dietary conditions*

\begin{tabular}{|c|c|c|c|c|c|c|}
\hline \multirow[b]{2}{*}{ Diet } & \multicolumn{2}{|c|}{ Glucose lipogenesis } & \multirow{2}{*}{$\begin{array}{l}\text { Significance } \\
\text { of difference } \dagger\end{array}$} & \multicolumn{2}{|c|}{ Acetate lipogenesis } & \multirow{2}{*}{$\begin{array}{l}\text { Significance } \\
\text { of difference }\end{array}$} \\
\hline & - Insulin & + Insulin & & - Insulin & + Insulin & \\
\hline & $\underset{\times 10^{-4}}{\mu g / \mu E q}$ & $\begin{array}{c}\mu g / \mu E q \\
\times 10^{-4}\end{array}$ & & $\begin{array}{c}\mu g_{.}^{\prime} \mu E q \\
\times 10^{-4}\end{array}$ & $\begin{array}{r}\mu g / \mu E q \\
\times 10^{-4}\end{array}$ & \\
\hline$P: F: C \ddagger=\underset{I}{=} 15: 0: 85$ & $\begin{array}{c}780 \pm 52 \S \\
\mathrm{n}=14\end{array}$ & $\begin{array}{c}901 \pm 71 \\
\mathrm{n}=14\end{array}$ & $\mathrm{p}<0.05$ & $\begin{array}{c}632 \pm 115 \\
\mathrm{n}=14\end{array}$ & $\begin{array}{c}991 \pm 275 \\
\mathrm{n}=14\end{array}$ & NS \\
\hline$P: F: C=\underset{I I}{15: 40: 45}$ & $\begin{array}{c}514 \pm 43 \\
\mathrm{n}=9\end{array}$ & $\begin{array}{c}590 \pm 84 \\
\mathrm{n}=9\end{array}$ & NS & $\begin{array}{c}88 \pm 22 \\
n=9\end{array}$ & $\begin{array}{c}244=48 \\
\mathrm{n}=9\end{array}$ & $\mathrm{p}<0.02$ \\
\hline$P: F: C=\frac{11}{\text { III }}$ & $\begin{array}{c}647 \pm 102 \\
\mathrm{n}=7\end{array}$ & $\begin{array}{c}813 \pm 146 \\
\mathrm{n}=7\end{array}$ & NS & $\begin{array}{c}237=42 \\
\mathrm{n}=7\end{array}$ & $\begin{array}{c}360=68 \\
n=9\end{array}$ & NS \\
\hline
\end{tabular}

* Serial incubations performed at approximately weekly intervals on subject E.H. All incubations were in bicarbonate buffer with $1 \mathrm{mg}$ glucose and $0.5 \mu \mathrm{c} \mathrm{C}^{14}$-glucose per $\mathrm{ml}$. When present, the insulin concentration was $0.1 \mathrm{U}$ per $\mathrm{ml}$.

$\dagger$ Levels of significance were calculated by Student's $t$ test. NS $=p>0.05$.

$\ddagger \mathrm{P}: \mathrm{F}: \mathrm{C}=$ per cent of total calories derived from protein, fat, and carbohydrate.

$\S$ Mean \pm standard error.

dition of albumin or gelatin to the medium and the use of several different batches of regular insulin at different concentrations up to $0.1 \mathrm{U}$ per $\mathrm{ml}$ have failed to give effects with human tissue similar to those found with the rat.

If, however, several estimations are made in an individual at intervals of several days, with tissue from the same site and at the precise same time after a standard meal, it is possible to show an occasional irregular effect on glucose and acetate lipogenesis when insulin is present in the incubation medium. The results of such an ex- periment are summarized in Table V. This subject was maintained at a constant caloric intake for many weeks solely on a liquid formula diet, the composition of which was varied so that during one period $40 \%$ of calories were supplied by fat (corn oil) and during the other two periods, a carbohydrate and protein mixture was the only source of calories. During each of these dietary periods, the average values for glucose and acetate lipogenesis were always higher when insulin was present in the incubation media. However, owing to the inherent variations exhibited by the tis-

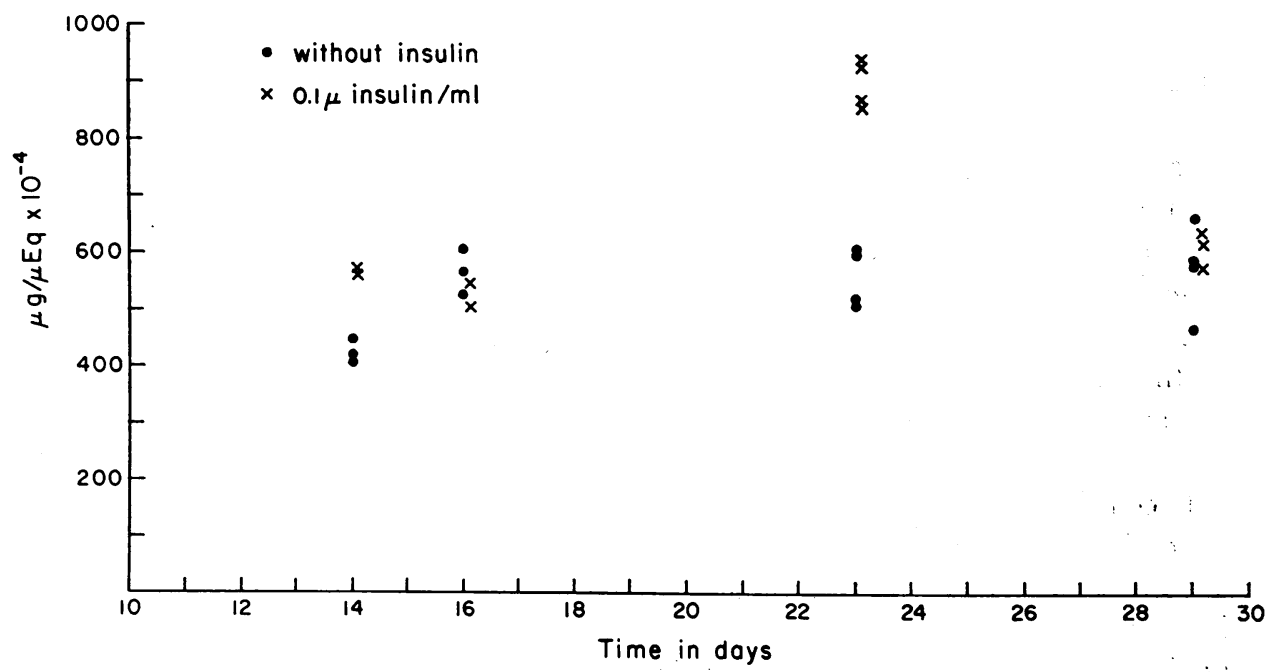

Fig. 4. INTERMitTency OF INSULIN EFFECT. The effect of insulin on glucose lipogenesis is shown during the midportion of dietary period II of subject E.H. (see Table V). Although averages for all observations during this dietary period show no significant insulin effect, it is clear that there were significant effects on days 14 and 23 . The data shown are replicate determinations performed with $(X)$ or without $(O)$ insulin added to the medium. 


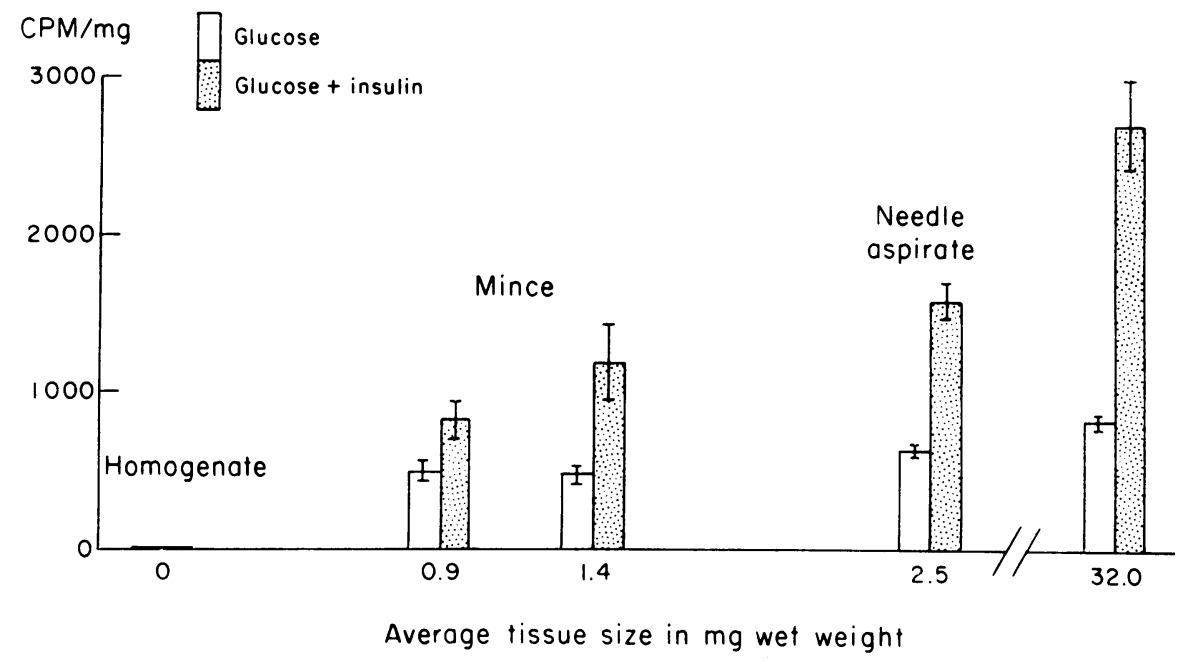

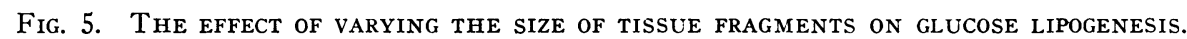
The epididymal pads of a 320-g Sprague-Dawley rat were cut into strips and minced or needled by aspiration. Various pieces were incubated in Krebs-Henseleit bicarbonate buffer with $1 \mathrm{mg}$ glucose and $1 \mu \mathrm{c} \mathrm{C} \mathrm{C}^{14}$-glucose per $\mathrm{ml}$ with or without $0.1 \mu$ of insulin per $\mathrm{ml}$. Mean \pm standard error of groups of tissue $(n=3)$ are shown. In each instance the average weight of a large number of fragments is shown. The tissue fragments were randomly selected from proximal, distal, and midportions of the same pad in order to randomize those effects attributable to location within the pad. Tissue strips averaging 32 $\mathrm{mg}$ in wet weight shown at the far right served as controls.

sues, a statistically significant insulin effect was not consistently demonstrated. The complexity of the insulin effect is further illustrated in Figure 4 , which contains representative individual values for glucose lipogenesis obtained in the midportion of dietary period II ( see Table V). On some days the tissues were evidently quite unresponsive to the presence of insulin, whereas on other days there was an appreciable enhancement of lipogenesis. In other subjects on a variety of diets, similar inconstant insulin effects were observed. On the basis of these findings, it would appear that the metabolic response of human adipose tissue to the presence of insulin in vitro is highly variable and on the whole is less marked than that observed with rat adipose tissue. The differences between human and rat tissues are partly, but not entirely, accounted for by the different techniques employed in procuring the fat and are further complicated by variations in metabolic activity exhibited by these small tissue shreds from one day to another. Both of these factors will be discussed below.

4) Effect of tissue size. The tissue trauma produced by the cutting and squeezing of tissue fragments during aspiration is appreciable. This is easily discernible, since large quantities of free floating fat droplets accompany each aspirate, indicating that many cells have been ruptured. The effects of such trauma on tissue metabolism were examined by comparing glucose lipogenesis with or without added insulin in fragments of different size. Epididymal fat pads were minced to various fragment sizes or needled and aspirated in order to make comparative observations. Large pieces of human subcutaneous adipose tissue obtained from patients undergoing surgery were similarly studied.

Figure 5 summarizes a study done with rat epididymal fat. Lipogenesis in large intact strips of tissue averaging $32 \mathrm{mg}$ in wet weight was compared with that in small fragments from the same fat pad obtained by needling or mincing. As the fragment size was reduced, there was also a slight reduction in glucose lipogenesis. A more significant reduction in lipogenesis with glucose and insulin occurred in the smaller pieces. In the unfortified homogenate, the extreme case of total cellular disruption, there was no demonstrable lipogenesis, with or without insulin. 
In several instances, large pieces (20 or more g) of human subcutaneous tissue were obtained during surgical procedures (laparotomy, femoral vein ligation, and so on). Results with the incubation of large tissue strips, averaging $50 \mathrm{mg}$ in wet weight, were compared with results obtained when the tissue was minced or needled. In general, all tissue fragments weighing $1 \mathrm{mg}$ or greater yielded similar results. Fragments below $1 \mathrm{mg}$ in weight produced either by needling or mincing showed lower values of glucose lipogenesis. In one instance a clear insulin effect could be demonstrated in the largest fragments and in intermediate size fragments, but in the smallest pieces, $0.4 \mathrm{mg}$ or less in size, glucose lipogenesis was roughly $50 \%$ lower, and an insulin effect was no longer detectable. The lesser effects of insulin on human adipose tissue when compared with the rat are thus in part due to the trauma involved in the aspiration and fragmentation of the tissue. In view of these results, small fragments $(<1$ mg) were excluded in all further experiments.

D) Distribution of label in incubated tissues. Incubation of human adipose tissue with labeled glucose, acetate, or FFA leads to a sufficient accumulation of counts in the lipid extract to permit an investigation of the degree of labeling in various lipid components.

The tissues of individuals on ad libitum or isocaloric formula diets incubated with $\mathrm{C}^{\mathbf{1 4}}$-glucose showed an average of $84 \%$ of counts in glycerideglycerol ; the remaining counts were found in fatty

TABLE VI

Per cent distribution of labeling of lipid classes during various incubations*

\begin{tabular}{lcccc}
\hline \multicolumn{1}{c}{ Lipid class } & Glucose & $\begin{array}{c}\text { Glucose } \\
+ \\
\text { insulin }\end{array}$ & Acetate & $\begin{array}{c}\text { Acetate } \\
+ \\
\text { insulin }\end{array}$ \\
\hline Triglyceride & 73.9 & 69.9 & 71.3 & 76.1 \\
FFA & 2.1 & 4.2 & 4.1 & 3.1 \\
$\begin{array}{l}\text { Cholesterol + } \\
\text { diglyceride }\end{array}$ & 23.4 & 25.5 & 24.0 & 20.5 \\
$\begin{array}{l}\text { Monoglyceride } \\
\text { +phospholipid }\end{array}$ & 0.5 & 0.3 & 0.5 & 0.4 \\
\hline
\end{tabular}

* Percentage of total counts recovered in various lipid classes separated by thin-layer silicic acid chromatography from four types of incubation with tissue removed from subject A.G. In all cases glucose, $1 \mathrm{mg}$ per $\mathrm{ml}$ in bicarbonate buffer, was used with appropriate tracer amounts of labeled glucose or acetate. Insulin when present was $0.1 \mathrm{U}$ per $\mathrm{ml}$. Incubations were carried out at $37^{\circ} \mathrm{C}$ for 4 hours.
TABLE VII

Per cent distribution of fatty acid labeling during various incubations*

\begin{tabular}{ccccc}
\hline \hline $\begin{array}{c}\text { Fatty acid chain } \\
\text { length: double } \\
\text { bonds }\end{array}$ & Glucose & $\begin{array}{c}\text { Glucose } \\
+ \\
\text { insulin }\end{array}$ & Acetate & $\begin{array}{r}\text { Acetate } \\
+ \\
\text { insulin }\end{array}$ \\
\hline & $\%$ & $\%$ & $\%$ & $\%$ \\
$12: 0$ & 1.1 & 1.5 & 0.6 & 0.8 \\
$14: 0$ & 9.3 & 11.6 & 6.8 & 6.5 \\
$16: 1$ & 3.2 & 1.8 & 2.2 & 1.1 \\
$16: 0$ & 58.0 & 57.5 & 52.5 & 57.8 \\
$18: 2$ and $18: 3$ & 0.1 & 5.2 & 0.4 & 0.5 \\
$18: 1$ & 19.5 & 8.7 & 20.8 & 10.4 \\
$18: 0$ & 6.7 & 12.7 & 12.9 & 20.9 \\
Remainder & 1.9 & 1.0 & 3.9 & 2.1 \\
& & & & \\
\end{tabular}

* Per cent of recovered counts in fatty acid. Methyl esters derived from total lipid extract of tissues (subject A.G.) separated by gas-liquid chromatography on a column of Celite particles coated with Apiezon. Remainder includes counts found in branched-chain, oddnumbered carbon methyl esters and methyl esters with chain lengths greater than 18. Tissues were incubated under the same conditions as described for Table VI.

acids. In contrast, close to $100 \%$ of the acetate counts incorporated were found in fatty acids. The effect of insulin on this distribution of isotope was not studied; however, the percentage of labeling of different lipid classes was found to be the same with glucose and acetate incorporation whether or not insulin was also present in the incubation medium. The results of such an investigation are shown in Table VI. Under the conditions of the separation, with triglyceride overloading the chromatoplates, trailing of triglyceride may be responsible for the majority of counts shown as FFA. A more precise evaluation of the degree of tissue FFA labeling by ionexchange chromatography was done on the extracts of tissues incubated with labeled fatty acid. With tissues from subjects on isocaloric diets, an average of only $1.2 \%$ of counts was found to be associated with FFA. As is shown in an accompanying report, tissues from fasted subjects contain a higher proportion of counts in tissue FFA.

The considerable radioactivity in the cholesterol-diglyceride area of the plate cannot be accounted for by triglyceride training. Further separation of zones in this area indicated that nearly all of the counts were present in diglycerides and not in cholesterol. The small activity in association with monoglycerides and phospholipids could well be artifactual.

The fatty acid methyl esters of the entire lipid 
extract were separately examined for radioactivity by gas-liquid chromatography as shown in Table VII. The predominant activity was associated with $16: 0$ in the various incubations. Small amounts of radioactivity in $18: 2$ and $18: 3$ were most likely due to tailing. The labeling of 18: 1 , which was surrounded by zones of lower radioactivity, undoubtedly reflected a true incorporation of counts into oleic acid rather than tailing from previous peaks. Lesser, but probably significant, radioactivity was found in 14:0 and 18:0. The differences in results among these incubations particularly in 18:1 and 18:0 may be of significance. Further studies will be necessary to establish the validity of the differences shown, since the above data were taken from a single study.

E) Average values. To obtain average or normal data for adipose tissue activity, observations were made on nine healthy young adults. These individuals were on a random diet and gave no history of recent weight changes. Tissues obtained by aspiration from the buttock yielded activities as shown in the first column of Table VIII. The data are expressed as means \pm coefficient of variation [( standard deviation/mean $) \times 100)]$. As can be seen, acetate incorporation into triglyceride was less than half that of glucose, although on a molar basis these incorporations of glucose and acetate were approximately equal (372.1 $\mu \mu$ moles and $365.1 \mu \mu$ moles, respectively).
The rates of FFA uptake and release were approximately equal during the 2-hour period of incubation.

An attempt was made to explore the basis for the variation in these results as shown by the coefficients of variation in the first column of Table VIII. Such variation could reflect true interindividual difference or might be due to 1 ) the combined errors of determination, i.e., pipetting, counting, and so forth;2) variations in activity from one tissue fragment to another, even though obtained in a single aspiration; or 3 ) differences in the same individual from day to day. The first possibility was examined by repeated determinations of lipid specific radioactivity from a single extract of incubated tissues. The coefficient of variation was only $1.4 \%$, representing a negligible contribution to the variations observed. The second and third possibilties were analyzed as shown in the second and third columns of Table VIII. The variations exhibited by tissue fragments obtained from a single aspiration were evidently great enough to represent a major contribution to the total variation. The day-to-day variations in metabolic activity exhibited by tissues obtained from the same individual maintained on a precisely controlled diet were as great or greater than those found when a series of different individuals was sampled at one time. Thus, the interindividual variations shown in column one would seem to reflect both a sampling varia-

TABLE VIII

Average values for metabolic activity of adipose tissue

\begin{tabular}{|c|c|c|c|}
\hline ' & $\begin{array}{l}\text { Interindividual variation: } \\
\text { 9 subjects on random diets* }\end{array}$ & $\begin{array}{l}\text { Variation of tissue shreds } \\
\text { obtained at a single } \\
\text { aspiration (A.S.) }\end{array}$ & $\begin{array}{l}\text { Seven observations on the same } \\
\text { individual (J.S.) at the same } \\
\text { site during } 40 \text { days on a rigidly } \\
\text { controlled isocaloric diet }\end{array}$ \\
\hline $\begin{array}{l}\text { Glucose, } \\
\qquad \mu g \times 10^{-4} / \mu E q \text {, in } 4 \text { hours }\end{array}$ & $\begin{array}{c}\% \\
664.4 \pm 16.6 \dagger \\
n=9\end{array}$ & $\begin{array}{c}\% \\
14.2 \ddagger \\
\mathrm{n}=12\end{array}$ & $\begin{array}{c}\% \\
27.0 \pm \\
\mathrm{n}=7\end{array}$ \\
\hline $\begin{array}{l}\text { Acetate, } \\
\qquad \mu g \times 10^{-4} / \mu E q, \text { in } 4 \text { hours }\end{array}$ & $\begin{aligned} 299.3 & \pm 88.5 \\
\mathrm{n} & =9\end{aligned}$ & $\begin{array}{l}12.6 \\
\mathrm{n}=12\end{array}$ & $\begin{array}{c}65.8 \\
\mathrm{n}=7\end{array}$ \\
\hline $\begin{array}{l}\text { FFA uptake, } \\
\mu E q / m E q, \text { in } 2 \text { hours }\end{array}$ & $\begin{aligned} 1.68 & \pm 38.1 \\
\mathrm{n} & =9\end{aligned}$ & $\begin{array}{l}12.5 \\
\mathrm{n}=12\end{array}$ & $\begin{array}{l}104.0 \\
\mathrm{n}=7\end{array}$ \\
\hline $\begin{array}{l}\text { FFA release, } \\
\mu E q / m E q, \text { in } 2 \text { hours }\end{array}$ & $\begin{aligned} 1.89 & \pm 43.9 \\
\mathrm{n} & =9\end{aligned}$ & & $\begin{array}{c}80.1 \\
\mathrm{n}=7\end{array}$ \\
\hline
\end{tabular}

* Inter- and intraindividual variations in tissue activity. All samples were obtained from the subcutaneous fat of the buttock. The nine subjects on random diets were medical students and laboratory technicians (six females and three males, ages 25 to 46 ) of average weight, free of disease or history of recent weight change. All were sampled 2 hours after breakfast.

$\dagger$ Mean \pm coefficient of variation.

$\ddagger$ Coefficient of variation. 
TABLE IX

Dietary effects on adipose metabolism*

\begin{tabular}{|c|c|c|c|c|c|c|c|}
\hline \multirow[b]{2}{*}{ Subject } & & \multicolumn{3}{|c|}{ Diet } & \multicolumn{3}{|c|}{ Significance of differences $\nmid$} \\
\hline & & $\begin{array}{c}\mathrm{P}: \mathrm{F}: \mathrm{C}=\mathrm{I} \\
\text { of calories }\end{array}$ & $\begin{array}{c}\mathrm{P}: \mathrm{F}: \mathrm{C}=15: 0: 85 \% \\
\text { of calories }\end{array}$ & $\begin{array}{c}\text { III } \\
P: F: C=15: 70: 15 \% \\
\text { of calories }\end{array}$ & $\begin{array}{l}\text { Diet I } \\
\text { vs. } \\
\text { diet II }\end{array}$ & $\begin{array}{l}\text { Diet II } \\
\text { vs. } \\
\text { diet III }\end{array}$ & $\begin{array}{l}\text { Diet III } \\
\text { vs. } \\
\text { diet I }\end{array}$ \\
\hline \multirow[t]{4}{*}{ J.S. } & $\begin{array}{l}\text { Glucose, } \mu g / \mu E q \\
\times 10^{-4}, \text { in } 4 \\
\text { hours }\end{array}$ & $\begin{aligned} 657.4 & \pm 67.2 \ddagger \\
\mathrm{n} & =7\end{aligned}$ & $\begin{array}{c}1,131.4 \pm 116.3 \\
n=4\end{array}$ & $\begin{array}{c}600.0 \pm 46.2 \\
n=9\end{array}$ & $\mathrm{p}<0.01$ & $\mathrm{p}<0.01$ & NS \\
\hline & $\begin{array}{l}\text { Acetate, } \mu g / \mu E q \\
\times 10^{-4}, \text { in } 4 \\
\text { hours }\end{array}$ & $\begin{aligned} 160.9 & \pm 40.0 \\
n & =7\end{aligned}$ & $\begin{array}{c}225.7 \pm 45.4 \\
n=4\end{array}$ & $\begin{aligned} 117.8 & \pm 18.2 \\
n & =9\end{aligned}$ & NS & NS & NS \\
\hline & $\begin{array}{c}\text { FFA uptake, } \mu E q / \\
m E q, \text { in } 2 \text { hours }\end{array}$ & $\begin{aligned} 3.89 & \pm 1.54 \\
\mathrm{n} & =7\end{aligned}$ & $\begin{array}{l}3.52 \pm 0.29 \\
\mathrm{n}=4\end{array}$ & $\begin{array}{c}3.34=0.54 \\
\mathrm{n}=9\end{array}$ & NS & NS & NS \\
\hline & $\begin{array}{l}\text { FFA release, } \\
\mu E q / m E q, \text { in } 2 \\
\text { hours }\end{array}$ & $\begin{aligned} 4.44 & \pm 1.35 \\
\mathrm{n} & =7\end{aligned}$ & $\begin{array}{l}3.06 \pm 2.25 \\
\mathrm{n}=4\end{array}$ & $\begin{aligned} 3.54 & \pm 0.89 \\
\mathrm{n} & =9\end{aligned}$ & NS & NS & NS \\
\hline \multirow[t]{2}{*}{ E.H. } & $\begin{array}{l}\text { Glucose, } \mu g / \mu E q \\
\times 10^{-4}, \text { in } 4 \\
\text { hours }\end{array}$ & $\begin{aligned} 514.1 & \pm 43.1 \\
\mathrm{n} & =9\end{aligned}$ & $\begin{array}{c}646.6 \pm 101.6 \\
n=7\end{array}$ & & NS & & \\
\hline & $\begin{array}{l}\text { Acetate, } \mu g / \mu E q \\
\times 10^{-4}, \text { in } 4 \\
\text { hours }\end{array}$ & $\begin{array}{c}88.2=21.9 \\
\mathrm{n}=9\end{array}$ & $\begin{array}{c}237.1 \pm 42.0 \\
n=7\end{array}$ & & $\mathrm{p}<0.01$ & & \\
\hline
\end{tabular}

* The effects of varying the proportions of fat and carbohydrate in the diet on the metabolic activity of adipose tissues: Both subjects were isocalorically maintained throughout the period of observation with formula feedings as the sole source of calories.

† Levels of significance were calculated by Student's $t$ test. NS $=p>0.05$.

$\ddagger$ Average \pm standard error.

tion at a given site and also the day-to-day variations in a given individual as much as any differences between individuals. For these reasons, it is important to obtain large samples for evaluation of adipose metabolic activity.

The possibility that dietary alterations might produce considerable change in adipose tissue activity was examined in two individuals (J.S. and E.H.) on isocaloric formula diets with widely different carbohydrate to fat ratios. Each patient was studied during different feeding periods, each period being of at least 1 month's duration. Adipose aspirations were done at approximately weekly intervals and always at the same time of day and at the same subcutaneous site. The results are shown in Table IX. Although the feeding of more carbohydrate led to higher average values for acetate and glucose lipogenesis, significance at the 0.05 level of confidence was not always found. It is notable that FFA uptake and release were unaffected by these dietary manipulations. Nonisocaloric feedings produce far greater changes in FFA metabolism as well as in glucose and acetate conversion to glyceride, as is shown in an accompanying communication.
F) Site-to-site variations. To assess the value of the aspiration technique in providing a representative measure of the metabolic activity of total body subcutaneous fat, comparisons were made between tissues removed from three regions, i.e., the arm, abdomen, and buttock. For this purpose five obese individuals (A.S., A.G.M., S.K., S.J., and E.K.) were studied. In most instances, the variations at each site were nearly as great as the intersite variations; however, in general, tissues from the arm appeared somewhat less active than those removed from the buttock and abdomen. No consistent differences could be found in FFA uptake and release. In one individual (A.S.), sufficiently large samples were obtained to enable replicate measurements at each site and a more complete statistical evaluation of the site-to-site differences. In another (A.M.) triplicate estimations made at each site on 3 successive days were pooled for analysis. The results are shown in Table X. Arm fat exhibited the lowest average levels of glucose and acetate lipogenesis, although the scatter of values at each site was such that significant differences were not consistently demonstrable. Comparisons of glucose and acetate 
TABLE $X$

Adipose metabolic activity at different subcutaneous sites

\begin{tabular}{|c|c|c|c|c|c|c|c|c|}
\hline \multirow[b]{3}{*}{ Subject } & & \multirow{2}{*}{\multicolumn{3}{|c|}{ Site }} & \multicolumn{4}{|c|}{ Significance of differences* } \\
\hline & & & & & \multirow{2}{*}{$\begin{array}{c}\text { Arm } \\
\text { vs. } \\
\text { abdomen }\end{array}$} & \multirow{2}{*}{$\begin{array}{c}\text { Abdomen } \\
\text { vs. } \\
\text { buttock }\end{array}$} & \multirow{2}{*}{\multicolumn{2}{|c|}{$\begin{array}{l}\text { Buttock } \\
\text { vs. } \\
\text { arm }\end{array}$}} \\
\hline & & Arm & Abdomen & Buttock & & & & \\
\hline \multirow[t]{3}{*}{ A.S. $\dagger$} & $\begin{array}{l}\text { Glucose, } \mu g / \mu E q \times 10^{-4} \\
\text { in } 4 \text { hours }\end{array}$ & $\begin{array}{c}361 \pm 10.9 \ddagger \\
\mathrm{n}=12\end{array}$ & $\begin{array}{c}401.6 \pm 15.8 \\
n=10\end{array}$ & $\begin{array}{c}388.6 \pm 15.9 \\
\mathrm{n}=12\end{array}$ & NS & NS & & NS \\
\hline & $\begin{array}{l}\text { Acetate, } \mu g / \mu E q \times 10^{-4} \\
\quad \text { in } 4 \text { hours }\end{array}$ & $\begin{array}{l}9.5 \pm 1.1 \\
\mathrm{n}=12\end{array}$ & $\begin{array}{c}19.7 \pm 5.0 \\
\mathrm{n}=12\end{array}$ & $\begin{array}{c}22.3 \pm 3.6 \\
\mathrm{n}=12\end{array}$ & NS & NS & $\mathrm{p}$ & $<0.01$ \\
\hline & $\begin{array}{l}\text { FFA uptake, } \mu E q / m E q \text {, } \\
\text { in } 4 \text { hours }\end{array}$ & $\begin{array}{c}1.56 \pm 0.11 \\
\mathrm{n}=12\end{array}$ & $\begin{array}{c}1.28 \pm 0.12 \\
\mathrm{n}=12\end{array}$ & $\begin{array}{c}1.52 \pm 0.06 \\
\mathrm{n}=11\end{array}$ & NS & NS & & NS \\
\hline \multirow[t]{2}{*}{ A.M. $\dagger$} & $\begin{array}{l}\text { Glucose, } \mu g / \mu E q \times 10^{-4} \\
\text { in } 4 \text { hours }\end{array}$ & $\begin{array}{c}683.1 \pm 87.0 \\
n=9\end{array}$ & $\begin{array}{c}1,420.9 \pm 304.5 \\
\mathrm{n}=9\end{array}$ & $\begin{array}{c}1,243.4 \pm 114.6 \\
\mathrm{n}=9\end{array}$ & $\mathrm{p}<0.05$ & NS & $\mathrm{p}$ & $<0.01$ \\
\hline & $\begin{array}{l}\text { Acetate, } \mu g / \mu E q \times 10^{-4} \text {, } \\
\quad \text { in } 4 \text { hours }\end{array}$ & $\begin{array}{c}112.7 \pm 17.1 \\
\mathrm{n}=9\end{array}$ & $\begin{array}{c}627.6 \pm 145.7 \\
n=9\end{array}$ & $\begin{array}{c}337.7 \pm 59.0 \\
n=9\end{array}$ & $\mathrm{p}<0.01$ & NS & $\mathrm{p}$ & $<0.01$ \\
\hline
\end{tabular}

* Levels of significance were calculated by Student's $t$ test. NS $=p>0.05$.

$\dagger$ Tissues were removed from subject A.S. by a single aspiration at each site done at the same time. Estimations on tissues from A.M. were done in triplicate on 3 successive days and the results pooled for the above analysis.

$\ddagger$ Mean \pm standard error.

lipogenesis in abdominal and buttock fat, and FFA uptake at all three sites, revealed no significant differences. Unfortunately, an adequate intersite comparison of free fatty acid release was prevented by the large amounts of tissue required for this determination. Nevertheless, it is evident that the metabolic activity of subcutaneous fat cannot be regarded as precisely uniform in all areas. For this reason we suggest that if serial measurements or interindividual comparisons of glucose and acetate lipogenesis are carried out, aspirations should be performed at the same anatomical site.

G) Relation of adipose activity to size of adipose depot. In attempting to understand what factors might cause variations in the levels of adipose activity, the effect of marked enlarge-

TABLE XI

Adipose metabolic activity in obese subjects

\begin{tabular}{lccccc}
\hline & $\begin{array}{c}\mathrm{S} . \mathrm{K} . \\
(\mathrm{n}=3)\end{array}$ & $\begin{array}{c}\mathrm{S} . \mathrm{J} . \\
(\mathrm{n}=1)\end{array}$ & $\begin{array}{c}\mathrm{E} . \mathrm{K} . \\
(\mathrm{n}=3)\end{array}$ & $\begin{array}{c}\mathrm{A} . \mathrm{M} . \\
(\mathrm{n}=5)\end{array}$ & Mean \\
\hline $\begin{array}{c}\text { Glucose, } \mu g \times 10^{-4} / \\
\mu E q, \text { in } 4 \text { hours }\end{array}$ & $652.9^{*}$ & $1,545.9$ & 611.3 & 817.5 & 906.9 \\
$\begin{array}{c}\text { Acetate, } \mu g \times 10^{-4} / \\
\mu E q, \text { in } 4 \text { hours }\end{array}$ & 120.4 & 47.4 & 660.4 & 363.3 & 297.9 \\
$\begin{array}{c}\text { FF A uptake, } \mu E q / \\
m E q, \text { in 2 hours }\end{array}$ & 2.06 & 0.90 & & & 1.48 \\
$\begin{array}{c}\text { FFA release, } \mu E q / \\
m E q, \text { in 2 hours }\end{array}$ & 1.18 & 1.78 & & & 1.48 \\
\hline
\end{tabular}

* Values obtained on four obese subjects (see Table I) on ad libitum diets during periods of weight maintenance. Each value is a mean value. ment of the adipose depot was considered. For this purpose, a series of observations was made on four obese individuals, as shown in Table XI. Since all data were expressed per unit of fat and these were individuals with a five- to tenfold increase in the size of the adipose depot, it is of interest to note that all values relating to FFA metabolism fell within $1 \mathrm{SD}$ of the average values obtained with individuals of normal body weight as given in the first column of Table X. Many of the values for glucose and acetate incorporation were well within this normal range, but several were higher. This sample is an insufficient basis for any conclusions as to differences in adipose tissue metabolism between obese and normal individuals, but suggests that activity of the tissue per weight of fat may not be very different. Since a great part of the fat present in obesity may be an inert store, it might be reasoned that the activity of such tissue relative to cytoplasmic mass or number of cells would be considerably different from normal. To test this possibility, measurements were also made of the nitrogen and DNA contents of adipose aspirates. The former would be expected to give an index of cytoplasmic mass and the latter to enable an approximation of the number of cells per aspirate.

As shown in Figure 6, the ratio of nitrogen to fat in three obese individuals was $1.28,0.91$, and 1.63. In one individual of average weight (J.S.), it was 1.12 ; and in a malnourished individual 
(C.K.) with greatly shrunken adipose depots, it was 1.41. Hence, the nitrogen to fat ratio (or mass of cytoplasm per unit fat) appears to change very little with marked obesity. Thus, measuring adipose activity in terms of nitrogen content offers little advantage to measurements per unit of fat.

DNA measurements per unit of fat are shown in the lower panel of Figure 6. Although the three obese individuals (S.J., S.K., and A.S.) had less DNA per unit of fat (or more fat per cell), the differences between the three groups were of small magnitude.

On the assumption that adipose tissue cells contain $7 \times 10^{-6} \mu \mathrm{g}$ of DNA per cell (17), an estimate can be made of the fat and nitrogen content per cell. The obese individuals averaged $47 \times 10^{-6} \mu \mathrm{Eq}$ of glyceride and $42 \times 10^{-6} \mu \mathrm{g}$ of $\mathrm{N}$ per cell, whereas it could be calculated that the adipose cells of the normal subject contained $39 \times$ $10^{-6} \mu \mathrm{Eq}$ of glyceride and $35 \times 10^{-6} \mu \mathrm{g}$ of $\mathrm{N}$. Unfortunately, these calculations ignore the contribution of DNA by endothelial and connective tissue cells. Yet there is a strong suggestion that hyperplasia of adipose cells with only slight increase in cellular size may have characterized the obesity in these few individuals. The presence of more cells of nearly normal dimensions would help to explain the rather similar levels of adipose metabolic activity of these obese individuals when the data are expressed per unit of fat. Further studies employing these techniques, as well as an independent histologic method for cell counting and sizing, are being undertaken to explore this point more thoroughly.

\section{Discussion}

The demonstration that viable human adipose tissue can be removed by an aspiration technique should have considerable application to the study of lipid and carbohydrate metabolism in man. As this investigation has shown, the same methods that have proven so useful in the study of the rat epididymal fat pad are applicable with minor modifications to the study of human tissues removed by aspiration.

One of the greatest limitations of this method is the difficulty in obtaining a sample that is rep-
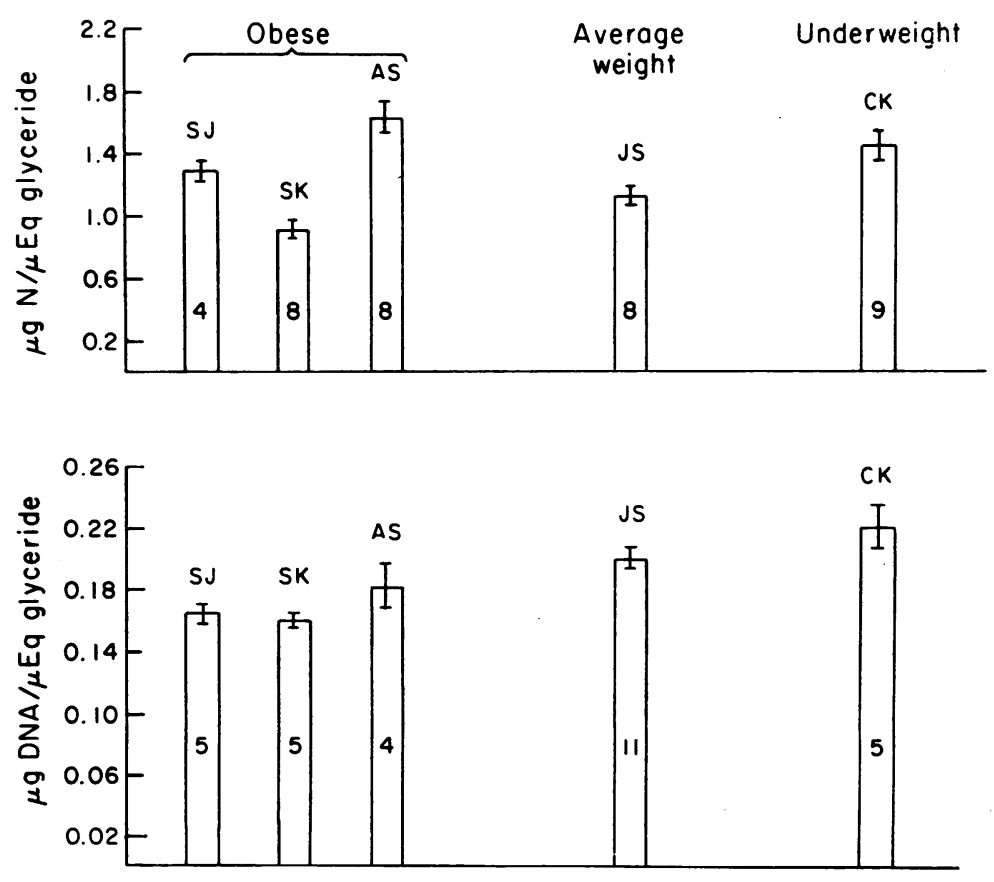

Fig. 6. Nitrogen and DNA to gLYCERIDE RAtios. Each bar represents a mean value \pm standard error. The number of observations is shown in each instance. All determinations were done on subcutaneous adipose tissue from the buttock. 
resentative of the entire adipose depot. Surprisingly, the variation in activity of tissue shreds removed in a single aspiration is at times as great or greater than the variations encountered when different sites in the same subject or even different subjects are studied. By this technique, the tissue shreds are removed from a roughly triangular area of subcutaneous tissue with a base and height each equal to several centimeters. Tissues are most likely removed from sites with different degrees of vascularity and different locations within the adipose tissue lobules. Such factors may be responsible for the variation in activity that is encountered. In a study of acetate lipogenesis in normal and lipomatous human adipose tissue, Gellhorn and Marks (26) observed exceedingly large interindividual differences even though incubations were carried out on large tissue slices removed at surgery; however, the variability of results from the same subject was not explored. Clearly, any evaluation of total adipose activity by aspiration should be done repeatedly in the same individual, obtaining large aspirates whenever possible. Although mean differences were not large in studies of tissues removed from different subcutaneous sites, the possibility of differences between subcutaneous fat and tissues from deeper adipose depots must be entertained. The nearly identical fatty acid composition of adipose tissue from superficial and deep depots in the same individual (3) suggests but by no means proves that the average metabolic activity is similar in both sites. In a recent publication of Hamosh, Hamosh, Bar-Maor, and Cohen (27), comparative studies of subcutaneous and mesenteric adipose tissue (both removed surgically) revealed considerably higher rates of lipogenesis in tissues from the mesenteric site.

In many qualitative aspects the results obtained with human adipose tissue are no different from the metabolic behavior observed by study of the rat epididymal fat pad. In both instances the incorporation of glucose label into tissue lipid is predominantly in glyceride-glycerol, whereas acetate label is found almost exclusively in glyceride fatty acids. As with rat adipose tissue, the small amount of diglyceride present in the tissue (found by thin-layer chromatography) develops high specific activity durin's the course of incubation with labeled glucose, acetate, or FFA, indicating the important role of diglyceride as an immediate precursor in triglyceride synthesis. The traces of monoglyceride found in the tissue are essentially unlabeled during incubation. Labeled acetate incorporated into long-chain fatty acids is distributed in a pattern that greatly favors palmitic and other saturated acids, a finding that would be expected if the enzymatic apparatus for fatty acid synthesis is the same in human adipose tissue as that reported for a variety of cellular systems in animals (23).

The findings that FFA with specific activity far higher than that of tissue glycerides are liberated during incubation of human tissue with labeled acetate is of some interest. This suggests a shunting mechanism whereby fat newly synthesized from carbohydrate by the adipose cell can be released without equilibrium with the entire pool of tissue glycerides. That a small, highly active intracellular pool might exist has been suggested by previous studies of the rate of change of human adipose composition under the influence of a new dietary fat (3), as well as by the work of Kerpel, Shafrir, and Shapiro (22), who were able to isolate a small pool of highly active glyceride during incubation of rat epididymal fat pads with labeled FFA.

A quantitative comparison of the results obtained in these studies with the activity in adipose tissue of 200 - to $300-\mathrm{g}$ rats reveals great similarity for rates of FFA uptake and release, but rates of glucose and acetate incorporation into glyceride only one-third to one-tenth as great as with the rat. These slower rates may reflect the fundamental difference in activity of a caloric storage tissue in man at a constant caloric intake as compared with the rat in positive caloric balance. An examination of adipose activity in children or adults during periods of rapid weight gain would provide further evidence on this point.

The use of average data to estimate the total activity of the adipose depot is fraught with many hazards. Nevertheless, if one assumes that there is uniformity of metabolic activity throughout the entire adipose depot and during a 24-hour period in an average individual with a $10-\mathrm{kg}$ adipose depot, then there will be conversion of $4 \mathrm{~g}$ of glucose into glyceride-glycerol and $0.7 \mathrm{~g}$ of fatty acid synthesis from acetate (either de novo or by chain elongation) but an influx and re- 
lease of FFA of $54 \mathrm{~g}$ per day. The errors involved in such calculations are very great, and at best these estimations represent minimal values. Apparently the value for glucose lipogenesis is grossly underestimated, since $4 \mathrm{~g}$ of glucose is adequate to provide only a little more than half the glycerol required for the esterification of 54 $g$ of FFA. The values for FFA uptake and release, even if underestimated, indicate the remarkably active flux of calories in and out of adipose tissue.

The frequent lack of response of human tissue to insulin stands in sharp contrast to the findings in rat adipose tissue. It seems unlikely that this is due exclusively to the tissue trauma produced by the technique of aspiration. However, the factor of tissue trauma combined with the over-all reduction and variability in lipogenetic activity in human tissue as compared with the rat may be sufficient to explain the differences observed.

It was surprising to observe that the small series of obese individuals displayed values for lipogenesis from acetate and glucose as well as values for FFA exchange remarkably similar to the nonobese subject. The fact that $\mathrm{N}$ or DNA to fat ratios are quite similar in the two groups would seem to indicate that human obesity is accompanied by a cellular increase in adipose tissue with cells that are normal according to the parameters evaluated in this study. Previous work on hypertrophy versus hyperplasia in obesity has suggested that both processes occur in the obese state $(28,29)$. The precise degree to which hyperplasia occurs in human obesity is now under more detailed study by a combination of the techniques described above with a morphologic approach to cell diameter and cell number.

\section{Summary}

A simple aspiration method for the serial sampling of human adipose tissue is described. The tissue shreds obtained have been studied in vitro to evaluate rates of lipogenesis from glucose and acetate, as well as release and uptake of free fatty acids. These studies lead to the following conclusions :

1) In normal human subjects, glucose lipogenesis averages $664.4 \mu \mathrm{g} \times 10^{-4}$ per $\mu \mathrm{Eq}$ of glyceride in 4 hours; acetate lipogenesis, 299.3 $\mu \mathrm{g} \times 10^{-4}$; and free fatty acid uptake, $1.68 \mu \mathrm{Eq}$ per $\mathrm{mEq}$ of glyceride in 2 hours, and release, 1.89 $\mu \mathrm{Eq}$ during the same time interval. In obese individuals the average rates are remarkably similar.

2) The activities of different tissue shreds at a given site are nearly as great a source of variability as the different activities found when comparing one subcutaneous site with another.

3) During incubation the adipose diglycerides as well as triglycerides are highly labeled. Palmitic and other saturated acids contain most of the labeling when acetate is used as precursor.

4) Isocaloric substitution of carbohydrate for fat in the diet produces only a small change in adipose tissue lipogenesis.

5) The effect of insulin on human adipose tissue obtained by this technique is variable and unpredictable.

6) The measurements of tissue nitrogen and DNA reveal that the content of nitrogen or DNA per unit of glyceride varies only slightly in a small series of obese, normal, and very thin individuals.

\section{Acknowledgments}

The capable technical assistance of Mrs. Carolyn Hunsicker is gratefully acknowledged, as is the help of Dr. E. H. Ahrens, Jr., in the preparation of the manuscript.

\section{References}

1. Shapiro, B., and E. Wertheimer. The metabolic activity of adipose tissue-a review. Metabolism 1956, 5, 79.

2. Portman, O. W., and F. J. Stare. Dietary regulation of serum cholesterol levels. Physiol. Rev. 1959, $39,407$.

3. Hirsch, J., J. W. Farquhar, E. H. Ahrens, Jr., M. L. Peterson, and W. Stoffel. Studies of adipose tissue in man-a microtechnic for sampling and analysis. Amer. J. clin. Nutr. 1960, 8, 499.

4. Ahrens, E. H., Jr., V. P. Dole, and D. H. Blankenhorn. The use of orally-fed liquid formulas in metabolic studies. Amer. J. clin. Nutr. 1954, 2, 336.

5. Goodman, DeW. S. Preparation of human serum albumin free of long-chain fatty acids. Science 1957, 125, 1296.

6. Dole, V. P. A relation betwen non-esterified fatty acids in plasma and the metabolism of glucose. J. clin. Invest. 1956, 35, 150.

7. Rapport, M. M., and N. Alonzo. Photometric determination of fatty acid ester groups in phospholipides. J. biol. Chem. 1955, 217, 193. 
8. Craig, L. C., W. Hausmann, E. H. Ahrens, Jr., and E. J. Harfenist. Determination of weight curves in column processes. Analyt. Chem. 1951, 23, 1326.

9. Mangold, H. K. Thin-layer chromatography of lipids. J. Amer. Oil Chemists' Soc. 1961, 38, 708.

10. Goldrick, B., and J. Hirsch. A technique for quantitative recovery of lipids from chromatoplates. J. Lipid Res. 1963, 4, 482.

11. Carlson, L. A., and L. B. Wadström. A colorimetric method of determining unesterified fatty acids in plasma. Scand. J. clin. Lab. Invest. 1958, 10, 407.

12. Stoffel, W., F. Chu, and E. H. Ahrens, Jr. Analysis of long-chain fatty acids by gas-liquid chromatography: micromethod for preparation of methyl esters. Analyt. Chem. 1959, 31, 307.

13. Farquhar, J. W., W. Insull, Jr., P. Rosen, W. Stoffel, and E. H. Ahrens, Jr. The analysis of fatty acid mixtures by gas-liquid chromatography: construction and operation of an ionization chamber instrument. Nutr. Rev. (suppl.) August 1959.

14. Meinertz, H., and V. P. Dole. Radioassay of low activity fractions encountered in gas-liquid chromatography of long-chain fatty acids. J. Lipid Res. 1962, 3, 140.

15. Ornstein, L. The distributional error in microspectrophotometry. Lab. Invest. 1952, 1, 250.

16. Patau, K. Absorption microphotometry of irregular-shaped objects. Chromosoma (Berl.) 1953, 5, 341.

17. Leslie, I. Nucleic Acid Content of Tissues and Cells in Nucleic Acids, E. Chargaff and J. N. Davidson, Eds. New York, Academic Press, 1955, vol. 2, p. 1.

18. Burton, K. A study of the conditions and mechanism of the diphenylamine reaction for the colorimetric estimation of deoxyribonucleic acid. Biochem. J. 1956, 62, 315.

19. Minari, O., and D. B. Zilversmit. The use of $\mathrm{KCN}$ for the stabilization of color in the direct nesslerization of Kjeldahl digests. Analyt. Biochem., in press.

20. Lubochinsky, B., and J. Zalta. Microdosage colorimétrique de l'azote ammoniacal. Bull. Soc. Chim. biol. (Paris) 1954, 36, 1363.

21. Lowry, O. H., N. J. Rosebrough, A. L. Farr, and R. J. Randall. Protein measurement with the Folin phenol reagent. J. biol. Chem. 1951, 193, 265.

22. Kerpel, S., E. Shafrir, and B. Shapiro. Mechanism of fatty acid assimilation in adipose tissue. Biochim. biophys. Acta (Amst.) 1961, 46, 495.

23. Wakil, S. J. Mechanism of fatty acid synthesis. J. Lipid Res. 1961, 2, 1.

24. Fredrickson, D. S., and R. S. Gordon, Jr. Transport of fatty acids. Physiol. Rev. 1958, 38, 585.

25. Winegrad, A. I., and A. E. Renold. Studies on rat adipose tissue in vitro. I. Effects of insulin on the metabolism of glucose, pyruvate, and acetate. J. biol. Chem. 1958, 233, 267.

26. Gellhorn, A., and P. A. Marks. The composition and biosynthesis of lipids in human adipose tissues. J. clin. Invest. 1961, 40, 925.

27. Hamosh, M., P. Hamosh, J. A. Bar-Maor, and H. Cohen. Fatty-acid metabolism by human adipose tissues. J. clin. Invest. 1963, 42, 1648.

28. Reh, H. Die Fettzellgrösse beim Menschen und ihre Abhängigkeit vom Ernahrungszustand. Virchows Arch. path. Anat. 1953, 324, 234.

29. Zingg, W., A. Angel, and M. D. Steinberg. Studies on the number and volume of fat cells in adipose tissue. Canad. J. Biochem. 1962, 40, 437. 